\title{
Tendências e relações entre a orientação sexual e 0 Cristianismo no Brasil ${ }^{1}$
}

Trends and relations between sexual orientation and Christianity in Brazil

\section{Uipirangi Franklin da Silva Câmara}

Doutor em Ciências da Religião pela Universidade Metodista de São Paulo, professor da Faculdade Teológica Batista do Paraná e das Faculdades OPET, membro e pesquisador do Núcleo Paranaense de Pesquisa e Estudo em Religião (NUPPER), Curitiba, PR - Brasil, e-mail: ucamara@gmail.com

\section{Resumo}

O presente artigo tem como pano de fundo um projeto que procura apresentar alternativas teológicas que deem conta de pensar a possibilidade e viabilidade de que pessoas homossexuais possam expressar sua espiritualidade de forma livre e completa nas comunidades cristãs brasileiras. Nesse sentido, procura apresentar um panorama da homossexualidade no Brasil, pontuando momentos diversos, valores, projetos e colocando em relevo a questão da identidade homossexual, principalmente, uma referência à mesma como perversão, anormalidade, crime e doença, reservando às pessoas homossexuais, o estigma, marginalização e exclusão. 0 texto procurará pontuar a busca por uma identidade alternativa por parte das pessoas homossexuais, tanto do

10 presente artigo nasce de um dos capítulos da tese de doutorado do autor em Ciências da Religião. No capítulo em questão pergunta-se com quem de fato os cristãos precisam tratar quando pensam em pessoas homossexuais. 
ponto de vista teórico, procurando novas possibilidades conceituais, quanto do ponto de vista político, articulando-se em busca de seus direitos como cidadãos.

Palavras-chave: Orientação sexual. Identidade. Cristianismo. Teologia. Pessoa humana.

\section{Abstract}

This article has as a backdrop a project that introduces theological alternatives which are able to think about the possibility and viability of homosexual people expressing their spirituality in a free and complete way in Brazilian Christian communities. For that purpose, it introduces an homosexuality overview in Brazil pointing out many moments, values, projects and emphasizing the homosexual identity issue, mainly a reference about it as perversion, abnormality, crime and illness, giving to homosexual people a stigma, marginalization and exclusion. This paper aims to show a search for an alternative identity by homosexual people, from the theoretic point of view, looking for new conceptual possibilities, and a political point of view of the people who, articulating themselves, seek their rights as citizens.

Parole-chiave: Sexual Orientation. Identity. Christianity. Theology. Human person.

Desde os degredados fanchonos (PIERONI, 2000, p. 134)2 até "maricas, bichas, viados, frescos, baitolas, perobos, babalus, quarilas, ativos, passivos, bâmbis, boiolas, lésbicas, sapatões, entendidos, entendidas, travecos, travestis, transexuais, bonecas, frutinhas, pederastas, efeminados, machonas, chibungos, bofenecas, sandalinhas, ladys, sapatas, michês, gays", são muitos os termos quando se quer, no Brasil, fazer referência à homossexualidade. Embora para diversos grupos ligados aos movimentos homossexuais existam diferenças bem nítidas entre a maioria desses termos, para o senso comum todos podem ser usados sem qualquer distinção às pessoas homossexuais ${ }^{3}$. Tal variedade é apenas um dos aspectos

2 Termo usado em Portugal como equivalente ao pecado de sodomia para os degredados ao Brasil em função da Inquisição Portuguesa.

3 Para o antropólogo Luis Mott: "Do mesmo modo como acontece entre os "heteros", que inclui tanto o machão como homens delicados, também entre os "homos" há grande diversidade de comportamentos, estilos de vida e estereótipos". Disponível em: <http://www.ggb.org.br/orienta-verdades.html>. Acesso em: 15 set. 2007

Rev. Pistis Prax., Teol. Pastor., Curitiba, v. 4, n. 1, p. 149-176, jan./jun. 2012 
de um contexto marcado pela complexidade, ambivalência e ambiguidade como a da homossexualidade. Peter Fry e Edward Macrae (1983, p. 7) sugerem que, para compreender a homossexualidade, é necessário olhar para "uma infinita variação sobre um mesmo tema: o das relações sexuais e afetivas entre pessoas de um mesmo sexo". Tal compreensão, no entanto, não evita uma pergunta vital: "Como saber o que é a homossexualidade quando nesta sociedade brasileira existem tantas opiniões contraditórias e mal-encontradas a respeito do assunto? Onde começar? Em quem acreditar?" (FRY; MACRAE, 1983, p. 9). De qualquer maneira, qualquer opção escolhida pode ser tomada como arbitrária, principalmente porque nem sempre é possível clarificar as razões metodológicas e as subjetivas que envolvem uma escolha de tal responsabilidade.

O presente artigo articular-se-á numa exposição que permita entender aspectos principais envolvendo a discussão em torno do tema da identidade homossexual no Brasil, pontuando certo registro histórico, preferências temáticas e referências sociais e políticas ${ }^{4}$, sempre, na medida do possível, a partir de fontes não ligadas às principais correntes cristãs no Brasil ${ }^{5}$. É certo que a discussão desse artigo privilegiará um recorte que não pode ser apontado como a verdade sobre a homossexualidade no Brasil, porque, entre outras coisas, também se configura como um movimento político identitário que reúne e abriga sob seu guarda-chuva conceitual uma diversidade considerável de sujeitos sociais (gays, lésbicas, transgêneros, bissexuais). Em segundo lugar, porque na homossexualidade, de forma implícita, consciente ou inconsciente, é possível observar outras "homossexualidades" diferenciadas, por exemplo, pela classe social ou posição cultural. Embora não possa ser considerada como a verdade sobre a homossexualidade, a discussão ensejada neste artigo ganha considerável sustentação por tentar reproduzir, o mais próximo possível, as vozes

(ver também: GRUPO GAY DA BAHIA, 1996).

4 Por referências sociais e políticas entenda-se a pauta comum defendida pelos diversos grupos de afirmação da homossexualidade no Brasil.

50 objetivo é tentar abordar o tema a partir da ótica dos grupos e pessoas homossexuais ou de pesquisadores cuja motivação principal seja um estudo mais distanciado possível de uma agenda religiosa de caráter apologético. 
ideológicas, políticas e sociais de quem fala, por enquanto, seja por eles mesmos, ou seus representantes constituídos ainda que informalmente.

Como nem sempre as retomadas históricas sobre o tema da homossexualidade no Brasil são concordes em certos aspectos ${ }^{6}$, apresentando muitas vezes informações fragmentadas e incongruências, elaborar um roteiro histórico não é uma tarefa tão simples e exige alguns cuidados metodológicos importantes. Portanto, para garantir certa legitimidade aos aportes históricos apresentados nessa investigação, o presente capítulo toma a obra ${ }^{7}$ dos antropólogos Peter Fry e Edward Macrae como balizador de pontos principais sobre o desenvolvimento ${ }^{8}$ do tema da homossexualidade no Brasil. Quanto aos aspectos relacionados à identidade do mundo homossexual, tais quais as aspirações em relação à sociedade, com recortes na política e religião, pretende-se como base principal de referência, sempre que possível, fontes utilizadas ou recomendadas pelos movimentos de afirmação gay ${ }^{9}$.

\section{Olhares históricos sobre a homossexualidade no Brasil}

É possível, pelo menos com uma certeza considerável, datar a presença de pessoas homossexuais no Brasil já no período colonial ${ }^{10}$. $\mathrm{O}$ ano de 1549 marca a chegada de Estevão Redondo, possivelmente o primeiro

\footnotetext{
6 Por exemplo, a divergência sobre quem foi Karoly Benkert (o primeiro a usar o termo homossexual em 1869). Para alguns autores, como Luis Mott, ele era um jornalista gay-húngaro (GRUPO GAY DA BAHIA, 1996). Para 0 psicólogo Ceccarreli. Disponível em: <http://www.ceccarelli.psc.br/artigos/portugues/html/ homossexueprec. $\mathrm{htm}>$. Acesso em: 20 out. 2007. Benkert era um médico húngaro. Diversos grupos, mesmo os ligados a grupos de afirmação gay, se referem à Karoly como uma médica húngara.

7 FRY, P.; MACRAE, E. 0 que é homossexualidade. 2. ed. São Paulo: a Brasiliense, 1983.. Entre os possíveis motivos para essa escolha, encontra-se 0 fato de que a quase totalidade de abordagens sobre 0 tema no Brasil nos últimos 20 anos, faz referência a essa obra.

8 A partir do que pode se pontuar como um provável início.

9 A presente pesquisa utiliza a expressão "grupos de afirmação gay" num sentido genérico, abarcando os diversos grupos abertos às principais reivindicações do movimento homossexual no Brasil.

10 Para Luis Mott (2007), a presença homossexual na história da Bahia é anterior inclusive à própria chegada dos colonizadores, pois, ao penetrarem na Terra dos Papagaios, portugueses e franceses encontraram e registraram, estupefatos, a existência de numerosos índios e índias praticantes do que a Cristandade chamava de "abominável e nefando pecado de sodomia".
}

Rev. Pistis Prax., Teol. Pastor., Curitiba, v. 4, n. 1, p. 149-176, jan./jun. 2012 
degredado de Portugal para o Brasil, pelo pecado de sodomia ${ }^{11}$. O pecado de sodomia era considerado o "mais torpe, sujo e desonesto de todos os crimes" (PIERONI, 2000, p. 136). E quando não era passível de pena de morte, a alternativa era o degredo ${ }^{12}$ ao Brasil. Embora seja possível identificar a presença de possíveis pessoas homossexuais no Brasil nesse período, só podemos falar em homossexualidade como um movimento organizado, buscando uma identidade distinta, bem mais tardiamente ${ }^{13}$.

Há certa concordância ${ }^{14}$ de que a edição do Jornal Lampião, em 1978, foi o marco no Brasil do surgimento do movimento homossexual organizado. Para Fry e Macrae, o jornal foi "editado no Rio de Janeiro por jornalistas, intelectuais e artistas homossexuais que pretendiam originalmente lidar com a homossexualidade procurando forjar alianças com as demais 'minorias', ou seja, os negros, as feministas, os índios e o movimento ecológico" (FRY; MACRAE, 1983, p. 21). O surgimento desse jornal possibilitou, na visão de Fry e Macrae, que "um grupo de artistas, intelectuais e profissionais liberais, descontentes com uma vida social restrita a boates e bares do "gueto' 15 homossexual" começassem a se reunir em São Paulo semanalmente dando origem, em fevereiro de 1979, ao primeiro grupo de afirmação homossexual no Brasil: O Somos ${ }^{16}$.

${ }^{11}$ Expressão usada para as relações sexuais entre pessoas do mesmo sexo ou ainda para as relações sexuais consideradas anormais (ex. sexo anal).

12 Entre os anos de 1587 a 1794, 0 antropólogo Luis Mott identificou cerca de 26 pessoas do sexo masculino condenadas ao degredo para o Brasil pelo pecado de sodomia (MOTT, L. J. Misericórdia: a inquisição portuguesa e a repressão ao nefando pecado de sodomia. In: NOVINSKI, A.; CARNEIRO, M. L. T. (Org.). Inquisição: ensaios sobre mentalidades, heresias e arte. Rio de Janeiro; São Paulo: Expressão e Cultura; EDUSP, 1992. p. 737).

13 Isso não significa que não se pudesse analisar certos traços distintivos de uma possível comunidade homossexual. Aliás, o antropólogo Luis Mott já apontou essa possibilidade em Portugal nos tempos da Inquisição (MOTT, L. Pagode português: a subcultura gay nos tempos inquisitoriais. Ciência e Cultura, n. 40, p. 120-139, 1988).

14 Para Luis Mott, 0 Lampião surge como decorrência da visita ao Brasil do editor do jornal Gay Sunshine, o jornalista Winston Leyland um ano antes. Fixando, portanto, 0 ano de 1977 como o marco inicial do movimento cf. Intelligentsia homossexual e militância gay no Brasil: De taturana a borboleta: a metamorfose de um antropólogo enrustido em militante gay. Disponível em: http:<//br.geocities.com/luizmottbr/artigos08.html>. Acesso em: 18 nov. 2007.

${ }^{15}$ A expressão gueto era geralmente usada como referência a grupos homossexuais urbanos.

16 O grupo "Somos" deixou de existir praticamente desde 1983. Atualmente há uma série de organizações que prestam homenagem ao "Somos", seja usando a designação "Somos" ou preservando publicações e 
A partir da criação do "Somos," os encontros para troca de ideias e debates acerca da questão homossexual no Brasil foi se intensificando. Não entrava em pauta apenas a busca por certa liberdade, certo direito de existir, mas também pelos fundamentos teóricos a partir dos quais o movimento homossexual no Brasil poderia se firmar. As principais propostas enfatizavam:

a) a autonomia do movimento homossexual em relação aos partidos políticos;

b) o apoio ao feminismo na luta contra o machismo e contra a reprodução do machismo nas relações homossexuais: dicotomia "ativo/ passivo", "dominador/dominado", "bofe/bicha", "fanchona/lady";

c) uma nova identidade homossexual marcada por relações sexuais/ afetivas essencialmente igualitárias (FRY; MACRAE, 1983, p. 24).

A atuação do movimento homossexual teve também ressonância interna. O "grupo de ação lésbico-feminista" levantou duas questões de fundo teórico-ideológico importantíssimas. Uma era o fato evidente de que eram os homens que dominavam as discussões e tomadas de decisões. A outra questão era que as mulheres consideravam um despropósito o fato de os homens "tratarem-se uns aos outros como se fossem as próprias mulheres" ${ }^{17}$. Problemas políticos, inclusive internos e financeiros, começam a desgastar o Somos e, de certa maneira, dispersar os projetos homossexuais.

O movimento homossexual ganha outro impulso considerável com a criação, em 1980, do Grupo Gay da Bahia. Fundado pelo antropólogo Luis Mott, o Grupo Gay da Bahia orgulha-se de ser, entre os grupos homossexuais criados, o mais antigo ainda em funcionamento na América Latina ${ }^{18}$.

\footnotetext{
documentos. Alguns dos documentos dessa época podem ser encontrados no Arquivo Edgard Leuenroth Disponivel em: <http://www.ifch.unicamp.br/ael/website-ael_institucional/website-ael_institucional.htm>. Acesso em: 18 nov. 2007.

17 FRY; MACRAE, 1983, p. 28. De certa maneira essas questões ainda permanecem pendentes.

18 Disponível em: <http://www.ggb.org.br/cronologia_movimento_homossexual.html>. Acesso em: 18 nov. 2007. Na verdade, o Grupo de Ação Lésbico-feminista e o Grupo Gay da Bahia são os únicos movimentos organizados de homossexuais que conseguem ultrapassar, como grupos atuantes, os anos 80 .
}

Rev. Pistis Prax., Teol. Pastor., Curitiba, v. 4, n. 1, p. 149-176, jan./jun. 2012 
Envolvido na defesa dos direitos dos grupos homossexuais e dos considerados afins ${ }^{19}$, o grupo organiza suas atividades em diversas frentes:

a) Orientação e apoio aos militantes (questões de saúde, direitos, segurança etc.);

b) Esclarecimentos sociais (História do movimento homossexual, termos relacionados aos homossexuais, discriminação, apoio etc.);

c) Ações de cunho político ou ideológico (denúncias, articulações junto a partidos políticos, Senado, Câmara, Poder Judiciário, Governo nas esferas Federal, Municipal e Estadual) além de incentivar uma produção teórica considerável ${ }^{20}$. Aliás, esse formato no qual o Grupo Gay da Bahia se estruturou tem sido uma marca característica dos inúmeros grupos, associações e parceiros da causa homossexual no Brasil contemporâneo.

Além do Grupo Gay da Bahia e dos inúmeros grupos no Brasil ${ }^{21}$, que de alguma forma estão ligados à causa homossexual, destaca-se também a Associação Brasileira de Gays, Lésbicas e Transgêneros ${ }^{22}$ $(A B G L T)^{23}$, fundada em 1995. Considerada como a maior rede nesse sentido da América Latina, a ABGLT reúne, no Brasil, 203 organizações, sendo 141 grupos de gays, lésbicas, travestis e transexuais, e mais 62 organizações colaboradoras voltadas para os direitos humanos e AIDS. Tendo como missão principal a promoção da cidadania e a defesa dos direitos de gays, lésbicas, bissexuais, travestis e transexuais, a ABGLT espera contribuir para a construção de uma democracia sem quaisquer formas de discriminação, afirmando a livre orientação sexual e identidades de gênero. Entre as suas principais ações, o grupo considera como prioridade:

\footnotetext{
19 Travestis, transexuais e transgêneros.

20 Boa parte de sua produção teórica pode ser consultada em: <http://www.ggb.org.br / welcome.html>. Acesso em: 15 set. 2007. Boa parte da visibilidade e respeito que o grupo tem conseguido deve-se em parte à liderança e militância do antropólogo Luis Mott.

${ }^{21}$ É possível encontrar na web uma série sobre associações e ONGs ligadas diretamente à causa homossexual ou que de alguma forma prestam algum serviço a essa causa.

22 Referência aos bissexuais, travestis e transexuais.

${ }^{23}$ É possível conferir características, bem como organizações parceiras no site do grupo. Disponível em: <http:// www.abglt.org.br/port/index.php>. Acesso em: 23 out. 2007.
} 
a) O monitoramento do programa "Brasil sem Homofobia"; 24

b) O combate à AIDS e outras doenças sexualmente transmissíveis;

c) Orientação sexual e Direitos Humanos no âmbito do MERCOSUL;

d) Advocacy ${ }^{25}$ para aprovação de leis e garantia de orçamento para políticas afirmativas voltadas para GLBT;

e) Capacitação de lideranças lésbicas em direitos humanos e advocacy;

f) Capacitação de operadores de direito em questões de cidadania GLBT.

Outro ponto de destaque nessa trajetória do movimento homossexual no Brasil foi a organização da "Parada do Orgulho Gay" de São Paulo, em 1997; nessa época, com a proposta de visibilização dos grupos de gays, lésbicas, bissexuais e transgêneros. O crescimento dessa manifestação ${ }^{26}$ deu origem, em 1999, à criação da "Associação da Parada do Orgulho de Gays, Lésbicas, Bissexuais e Transgêneros", uma organização civil com o objetivo de defender a diversidade sexual, lutando por uma sociedade mais justa e inclusiva, que reconheça direitos iguais para todos. ${ }^{27}$

Evidentemente, cada grupo tem sua importância no cenário de afirmação da causa e da pessoa homossexual no Brasil. Frutos da própria diversidade cultural e ideológica que permeia o país, cada um, a seu modo, conquista espaços e aceitação cada vez maiores. No entanto, as organizações, passeatas e bandeiras político-ideológicas do movimento homossexual no Brasil, nos diversos projetos em prol da visibilidade da identidade homossexual, não conseguem ainda colocar, de forma satisfatória, em sua agenda o item identidade homossexual. Como pode se

\footnotetext{
24 Programa organizado pela Secretaria Especial dos Direitos Humanos do Governo Brasileiro que prevê uma parceria entre o Governo e a Sociedade Civil Organizada, para 0 combate à violência e à discriminação contra GLTB e de promoção da cidadania homossexual. Disponivel em: <http://www.aids.gov.br/data/ Pages/ LUMISE047F607PTBRIE.htm>. Acesso em: 17 jan. 2008.

${ }^{25}$ Termo inglês, usado nesse contexto para busca de apoio para os direitos da pessoa e causa homossexual, principalmente, a partir de ações junto aos poderes representativos do País.

${ }^{26}$ Estima-se que a primeira manifestação em 1997 tenha começado com 2.000 pessoas e hoje tem atingido em 2007 a marca de 3.500.000, incluindo simpatizantes, ver reportagem do portal Terra, divulgada em 10 de junho de 2007. Disponível em: <http://exclusivo.terra.com.br/ paradagay2007/interna/0, 0l1679129El9099,00.html>. Acesso em: 16 jan. 2008.

27 Disponivel em: <http://www.paradasp.org.br/modules/articles/article.php?id=2>. Acesso em: 16 jan. 2008.
} 
definir uma pessoa homossexual? De que maneira identidade e ideologia se relacionam?

\section{A identidade homossexual no Brasil: outras articulações}

Na busca pela causa comum, os muitos movimentos produzidos pelos diversos grupos homossexuais, de certa maneira, estão envolvidos na construção de uma identidade que os represente de maneira satisfatória. $\mathrm{Na}$ verdade, tal projeto identitário pretende constituir-se a partir de uma "articulação de vários recortes identitários aparentemente segmentados gays, lésbicas, bissexuais, travestis e transexuais" (FRANÇA; SIMÕES, 2005). Esse projeto torna-se necessário porque em função da "gradual redução do estigma social a homossexualidade se esconde menos" (FRY; MACRAE, 1983, p. 32) e, ao mostrar-se mais, ela mostra seus diferentes rostos: "Há toda uma gradação entre a 'bicha' ligeiramente efeminada até o travesti, como há uma mesma gradação entre o 'sapatão' vagamente masculinizado e a 'mulher-macho' mesmo" (FRY; MACRAE, 1983, p. 47). Perscrutar a profundidade da identidade homossexual no Brasil não é uma tarefa fácil. É tênue a fronteira do ideológico para o real, do político para o imaginado. Portanto, pensar a identidade homossexual no Brasil é - longe de analisar envolver-se num projeto de rastreamento. Projeto esse que envolve perguntas por fatores ou momentos constitutivos do que seja possível compreender na expressão homossexualidade, quando o foco é a identidade.

Durante certo tempo, foi a religião que assumiu a tarefa de estabelecer as principais definições sobre a homossexualidade. Na época colonial, por exemplo, é possível percebê-la nas "Constituições Primeiras do Arcebispo da Bahia em 1707” (FRY; MACRAE, 1983, p. 60) como um "hediondo pecado, péssimo e horrendo, provocador da ira de Deus e execrável até pelo próprio Diabo". Homossexualidade ${ }^{28}$ era definida a partir da relação do sujeito com as normas religiosas e era essa relação que, por conseguinte, o definia socialmente. Como pode, por exemplo, se observar nas definições médicas sobre a homossexualidade. Partindo

${ }^{28} 0$ termo mais usual no período era sodomia. 
de uma questão religiosa, sem abandoná-la, a medicina define também a homossexualidade como uma questão de saúde: "Mais que todos os seres, o homem, pelas suas paixões e por seus instintos libidinosos, corrompe e arruína a própria saúde, destruindo as fontes da vida" ${ }^{29}$. Dessa maneira, não apenas os religiosos, mas também serão "os médicos que reivindicarão a sua autoridade de falar a verdade sobre a sexualidade e serão eles os agentes da gradual transformação da homossexualidade de 'crime', 'sem-vergonhice' e 'pecado' para 'doença' (FRY; MACRAE, 1983, p. 61). E ao longo dos anos que se seguem: o crime merece punição, a doença exige a "cura". Portanto, a identidade de uma pessoa homossexual é marcada pelo não reconhecimento de sua dignidade como pessoa humana, restando-lhe, portanto, o estigma, a marginalização, o remédio, a conversão.

O primeiro trabalho acadêmico (GREEN, 2005, p. 55) brasileiro que buscou fugir desse ciclo pecado/crime/cura (Religião/Polícia/Medicina) foi produzido nos anos 1950. Umas das motivações principais dessa pesquisa foi a superação dessa abordagem cíclica, ou pelo menos a diminuição da "importância dos juízos valorativos e das condições de policiamento" para que se pudesse agregar, de fato, um conhecimento mais profundo sobre a homossexualidade. Nessa perspectiva, o viés sociológico foi o novo componente metodológico para compreensão da homossexualidade, com a esperança de que os aspectos sociais e culturais pudessem explicitar o que o moral e biológico já em uso não estavam dando conta. A partir desse novo enfoque, a homossexualidade passa a ser compreendida a partir de uma relação que contrapõe grupo minoritário/estigmatizado versus grupo majoritário dominador/estigmatizador ${ }^{30}$.

O que importa conhecer sobre os grupos minoritários não é apenas a sua posição, mas os padrões de comportamento que eles desenvolvem e a imagem que possuem de si mesmos e dos outros. Na maior parte dos casos, os grupos minoritários estão colocados em uma situação de conflito em relação ao grupo dominante e à sua não participação na vida da sociedade inclusiva, ou em certos aspectos desta que, mais particularmente, os marca

\footnotetext{
29 Palavras de um médico carioca em 1906. Citado por FRY; MACRAE, 1983, p. 61.

${ }^{30}$ Essa não é apenas uma afirmação metodológica, os diversos grupos homossexuais interiorizam essa concepção nas explicações que permeiam a autocompreensão de sua identidade.
}

Rev. Pistis Prax., Teol. Pastor., Curitiba, v. 4, n. 1, p. 149-176, jan./jun. 2012 
como tal e perpetua sua posição minoritária [...]. A posição minoritária do grupo homossexual acarreta, por conseguinte, uma série de restrições que circunscrevem a liberdade individual e o autodesenvolvimento. Por isso, os indivíduos do grupo minoritário (e igualmente aqueles que, por qualquer circunstância, a associação é descoberta) encontram barreiras ao desenvolvimento de sua vida social e de sua liberdade pessoal, pois é diretamente contra eles que o grupo majoritário pode exercer claramente ações discriminatórias (GREEN, 2005, p. 58-60).

A compreensão da homossexualidade ganhou outro componente importante nessa perspectiva, ou seja, incidirá em erro quem pensar em "identidade" homossexual a partir da noção de unidade, de univocidade. A organização ou autodefinição como grupo minoritário não significa totalmente subsunção em uma identidade única, mas sim, o arranjo de múltiplas identidades em torno de uma causa comum. Nesse caso, as pessoas homossexuais

[...] devem ter desenvolvido uma consciência de que não são um caso individual dentro da sociedade inclusiva, mas que existem outros que fizeram semelhante opção e que todos, nessa condição, compartilham de certas áreas de interesse que os levam ao estabelecimento de relações sociais e à participação no grupo minoritário (e na sua cultura), mesmo que de forma periférica (GREEN, 2005, p. 58-60).

Embora os grupos homossexuais, principalmente, por uma questão de segurança e sobrevivência, tivessem que demonstrar externamente certa unidade identitária (programática?), internamente, as relações revelavam tensões (econômicas, sociais, políticas) ${ }^{31}$. Esse compromisso identitário político que começava a se desenhar, precisava também, no campo conceitual, abordar certa insistência sobre estereótipos, concepções equivocadas em relação às pessoas homossexuais, como por exemplo, "os homossexuais masculinos são efeminados e as lésbicas, masculinizadas":

${ }^{31}$ Diversas classes sociais estão entremeadas os grupos homossexuais com interesses, muitas vezes, contraditórios. Para alguns estudiosos, os homossexuais de classe média são o grupo organizador da cultura homossexual. Ver, por exemplo, GREEN, J. N.; TRINDADE, R. (Org.). Homossexualismo em São Paulo e outros escritos. São Paulo: Ed. da UNESP, 2005. p. 88. 
na visão do senso comum, todo homossexual, necessariamente, se enquadra no estereótipo persistente de um homem [...] com traços delicados e físico frágil, e que imita as mulheres, e por isso mesmo é, apropriadamente designado de "boneca" ou "bichinha"... Do contrário, o homossexual ativo para o qual, no Brasil, se criaram os termos bofe, fanchão, etc.... tende a ganhar status de mais macho. Nesse sentido, Fry (1982, p. 68) diz que, "com muito poucas exceções, os machos que comem bichas não são classificados de maneira diferente dos homens verdadeiros devido ao seu desempenho do papel ativo" (SILVA, 2002, p. 2) ${ }^{32}$.

Conscientes de alguns dos estereótipos atribuídos pelo senso comum, até por uma atitude de autopreservação, alguns homossexuais tentavam "encobrir, da melhor maneira possível, as características simbólicas do homossexualismo" (GREEN; TRINDADE, 2005, p. 77), ou seja, alguns apresentavam um comportamento social perante a sociedade, escondendo sua opção sexual, ao apresentarem-se, por exemplo, como heterossexuais. Por outro lado, no plano interno, os próprios homossexuais encarregavam-se de regular, segundo os vários padrões e tendências internas, o comportamento de seus membros:

dessa forma, em uns é o comportamento efeminado que é sancionado positivamente e esperado de todos os membros, enquanto em outros, a exibição de papéis efeminados levaria à exclusão do grupo primário. Em uns, as relações sexuais passivas são sancionadas como ideal único para os membros, enquanto em outros, a seleção única desse tipo de relação sexual é ridicularizada (GREEN; TRINDADE, 2005, p. 105).

Tais constatações não surgem na esteira de qualquer julgamento moral, pelo contrário, realçam as contradições e complexidades de uma definição (ou busca por uma) de uma possível identidade homossexual num feixe de uma série de outras identidades. Identidades que se fundem ou se abrem em relação a uma série de fatores das mais diversas ordens ${ }^{33}$.

\footnotetext{
32 Para NUNAN, A. Homossexualidade: do preconceito aos padrões de consumo. Rio de Janeiro: Caravansarai, 2003. p. 20. "A maioria dos homossexuais não está confusa no que se refere a sua identidade de gênero: tem certeza de serem homens/mulheres, e poucos adotam um comportamento efeminado/ masculinizado".

${ }^{33}$ Alguns homossexuais precisam viver ainda na clandestinidade, sejam por pressões familiares, religiosas, políticas ou econômicas. Outros, pelo contrário, têm como opção de sobrevivência a prostituição.
}

Rev. Pistis Prax., Teol. Pastor., Curitiba, v. 4, n. 1, p. 149-176, jan./jun. 2012 
De qualquer maneira, é sempre boa a advertência metodológica de não se fazer uso político de certas análises: a parte não pode explicar, tampouco justificar o todo (NUNAN, 2003, p. 29). Aliás, a busca por certa identidade comum pode ser um equívoco metodológico que necessite ser contornado. Néstor Perlongher (2005, p. 264), por exemplo, para evitar o que considerava "certo vício de origem" essencialista do conceito de identidade, a partir do qual, era retratada como uma imagem coerente que os sujeitos teriam que fazer de si mesmos como se fossem "entidades unificadas, fechadas e excludentes" (PERLONGHER, 2005, p. 264) propôs uma abordagem territorial. Tal abordagem

[...] permitiria representar mais adequadamente as categorias de autodefinição sexual como "pontos" dentro de redes circulatórias, numa relação de contiguidade e mesmo de mistura. Isso poderia ser verificado tanto nos espaços e trajetos percorridos pelos sujeitos quanto pela posição dos sujeitos em diversas relações, o que faz com que eles se qualifiquem e sejam qualificados de maneiras diferentes, conforme o lugar em que estejam, valendo-se de uma proliferação de categorias identitárias que colidem e tensionam entre si. A ênfase nas "identidades" seria, assim, substituída pela ênfase em "territorialidades", "lugares relacionais" e "lugares categoriais" de modo a captar como os sujeitos se definem mutavelmente a partir de "posições" e "trajetórias" (ou "devires") variáveis dentro de uma rede, bem como da participação de diferentes redes.

Para ele, os espaços nos quais circulam, transitam e se encontram as pessoas homossexuais dão pistas hermenêuticas a respeito de seus valores, gostos, projetos e classificações. Essa abordagem proposta por Néstor Perlongher deixa à mostra um problema metodológico na análise teórica dominante em relação às pessoas homossexuais, principalmente no tocante ao reconhecimento de uma identidade que não seja marcada negativamente (crime, doença, perversão, pecado, etc.), ou seja, tais análises eram feitas, em sua maioria, a partir de fora, do já escrito e não da vivência homossexual. Perspectiva que já sinalizava para o perigo conceitual de se falar em identidade homossexual insistindo em certa classificação (problematização?) da pessoa homossexual. 
A perspectiva de representação diante dos novos desafios sociais faz nascer, dentro do movimento homossexual, um projeto identitário formulado a partir de um argumento principal: afirmação da dignidade humana sobre quaisquer rótulos e classificações. Tal projeto deve principiar-se por uma hermenêutica que parta da pessoa homossexual, de seus valores, de suas relações familiares, afetivas, de trabalho. Hermenêutica que leve em conta suas contribuições à sociedade, seja por meio de seu trabalho, seja por meio de seu engajamento nas questões que envolvam a responsabilidade social e ambiental.

\section{As vivências homossexuais no Brasil: a busca interna por uma noção de identidade}

Por vivências, entendam-se os encaminhamentos que os homossexuais têm ensejado para que a sua inserção e visibilidades sejam cada vez mais notórias no cenário brasileiro da contemporaneidade. Embora não se possa fechar os olhos ao "modelo de mercado" (MACRAE, 2005, p. 292) ) $^{34}$ idealizado para configurar certo modelo de pessoa homossexual, a verdade é que a inserção na sociedade brasileira pelas pessoas homossexuais, de forma cada vez mais consistente e visível, tem sido prioridade na agenda de diversos grupos representativos da causa homossexual. Não se trata apenas de elaborar um discurso ideológico de aceitação e reconhecimento social, mas sobretudo de garantir a dignidade de "existir" resistindo a discriminações, perseguições físicas e morais e, em muitos casos, as incertezas de garantias às próprias vidas. Esse duplo papel é desempenhado em duas frentes de maneira mais ou menos geral. Internamente, procura-se trabalhar com questões ligadas aos homossexuais, geralmente trazidas por eles mesmos ou surgidas a partir de suas histórias de vida. Externamente, trabalhando pela cessação de certa atitude repressora observada em muitos setores da sociedade (MACRAE, 2005, p. 296). Edward Macrae concorda no

\footnotetext{
${ }^{34}$ MACRAE, E. Em defesa do queto. In: GREEN, J. N.; TRINDADE, R. (Org.). Homossexualismo em São Paulo e outros escritos. São Paulo: Ed. da UNESP, 2005. p. 292, chama esse modelo de "exploração comercial do homossexual".
}

Rev. Pistis Prax., Teol. Pastor., Curitiba, v. 4, n. 1, p. 149-176, jan./jun. 2012 
fato de que essa busca das pessoas homossexuais por espaço e visibilidade é importante em relação à própria conduta da sociedade, pois o "aumento do número de homossexuais visíveis tem levado a população como um todo a dar mais atenção ao fenômeno e tem promovido a ideia de que podem existir diversas orientações sexuais, todas válidas" (MACRAE, 2005, p. 298). Por outro lado, essa nova postura também é importante para os próprios homossexuais, pois altera a forma como eles se veem e se relacionam:

embora continue a vigorar uma série de fatores inconscientes, acessíveis só por análises profundas é inegável que discussões entre amigos e a força do exemplo ajudam imensamente as pessoas a se sentirem menos culpadas em relação à sua conduta sexual. Não é a toa que uma das atividades mais bem-sucedidas dos grupos homossexuais seja a formação de grupos de reflexão e troca de experiência (MACRAE, 2005, p. 299).

De certa maneira, observa-se como tendência contemporânea, na busca por essa nova "vivência" homossexual, uma espécie de fuga de sentimentos de culpa, pecado, "medo do ridículo, da prisão, do desemprego, do ostracismo por parte de amigos e familiares" (MACRAE, 2005, p. 299) e um anseio por uma nova identidade social em que já seja possível viver sem ter de carregar o peso do estigma, da exclusão e do crime. Há um esforço programático no sentido de que "tanto a sociedade como um todo, quanto os indivíduos homossexuais reavaliem a imagem do homossexual" ${ }^{35}$. No entanto, não é fácil viabilizar essa busca por uma vivência alternativa, esse esforço para construir uma nova identidade a partir de uma identidade marginal:

HOMOSSEXUAL NEM SEMPRE É HOMOSSEXUAL. O heterossexual, sim. Em todas as relações sociais, profissionais e familiares, sua orientação sexual é sempre uma parte de sua identidade essencial. O homem heterossexual entra em relação com os homens e as mulheres de um certo modo, que exprime abertamente sua orientação, globalmente invariável. A mulher heterossexual tem gestos, condutas e maneiras de falar que refletem não somente sua feminilidade, mas também sua heterossexualidade. Nos dois casos, sexo

35 Edward Macrae (2005, p. 309-336) já constatava essa articulação de grupos homossexuais em prol de uma visibilidade social mais ampla e crescente há 20 anos, quando defendia a importância dos guetos como lugar privilegiado de ebulição dessa tendência. Sobre a importância do gueto, características e reatualização do conceito. 
biológico, orientação sexual e papéis sociais tendem a convergir e formar uma identidade relativamente estável (MACRAE, 2005, p. 309-336) ${ }^{36}$.

Pedro de Souza prefere o termo subjetividade (SOUZA, 1997) para designar o que chama de problema da constituição e expressão da subjetividade na história de afirmação do movimento homossexual no Brasil. Para ele, subjetividade nesse sentido pode ser entendida como "certo universo imaginário da experiência vivida, em que o indivíduo percebe-se como unidade separada e diferenciada ao lado de outros com os quais partilha o mesmo espaço social de confrontos e coerções" (SOUZA, 1997, p. 11). A pessoa homossexual busca um modo de falar de si como sujeito constituído que já não se contenta em sê-lo sob a égide da exclusão. Por isso, esse sujeito encontra na extrapolação de algo (sua sexualidade) que deveria manter-se na esfera do pessoal e do privado para o público (SOUZA, 1997, p. 14-15), a fim de afirmar-se como alguém que tem direito não apenas à visibilidade, mas, sobretudo, a uma espécie de dignidade que deve permear o sujeito humano, apesar de suas igualdades e diferenças: "Perceber-se diferente é, ao mesmo tempo, liberdade e tensão. O desafio, no plano da esfera pública, constitui-se na busca de tornar enunciável uma prática sexual diferente e dizer-se sujeito dela" (SOUZA, 1997, p. 23) ${ }^{37}$. Nesse sentido, é preciso compreender que "o homossexual não se desloca no mundo com uma identidade constante" (SOUZA, 1997, p. 19). Ele precisa repensar suas atitudes e comportamentos em função de uma diversidade de variáveis: "Ele pode parecer heterossexual no escritório, assexuado na família, e expressar sua orientação sexual somente na presença de alguns amigos". Essa questão toma uma dimensão ainda maior quando se pergunta pelo exercício de um papel, de certa identidade, para a qual não foi preparado:

o heterossexual foi educado para sê-lo; desde a mais tenra infância, foi formado para um papel e um lugar no mundo heterossexual. Este não é o

\footnotetext{
${ }^{36}$ CASTAÑEDA, M. A experiência homossexual: explicações e conselhos para os homossexuais, suas famílias e seus terapeutas. São Paulo: A Girafa, 2007, chama esse processo de "uma identidade mutante".

${ }^{37}$ SOUZA, P. Confidências da carne: o público e o privado na enunciação da sexualidade. Campinas: Ed. da Unicamp, 1997. p. 23.
}

Rev. Pistis Prax., Teol. Pastor., Curitiba, v. 4, n. 1, p. 149-176, jan./jun. 2012 
caso do homossexual, que muitas vezes só toma consciência de sua orientação sexual no decorrer da adolescência ou da idade adulta. Portanto, ele não cresceu em seu papel: não foi educado para ser homossexual. Falta-lhe todo tipo de habilidades e de códigos sociais de que necessitará em um mundo homossexual, que será o seu (SOUZA, 1997, p. 20).

Essa "carência de aprendizagem" (SOUZA, 1997, p. 19) ${ }^{38}$ permite que as pessoas homossexuais busquem novas vivências como alternativas para superá-la. Há uma consciência cada vez mais crescente que essa identidade "homossexual", que não é dada, deve ser construída aos poucos com a conscientização que nem sempre se expressará da mesma maneira de uma pessoa heterossexual. As relações de uma pessoa homossexual consigo e com os outros

são muito diferentes; nesse sentido, poderíamos dizer que o homossexual vive em um universo interior muito diferente, e que, na maior parte do tempo, não se vê do lado de fora. Muitos homossexuais tentam, de fato, se tornar invisíveis e passar por heterossexuais aos olhos da sociedade, de sua família e de seus amigos... A homossexualidade - e, suas práticas e suas dinâmicas - não é uma cópia mal feita de um original que seria a heterossexualidade; tampouco um fenômeno equivalente (CASTAÑEDA, 2007, p. 20-21).

Esse processo de construção de uma nova identidade é efetivado com o aprendizado. A expressão preferida por muitas pessoas e grupos pró- homossexuais, além de pesquisadores para sintetizar esse "espírito contemporâneo" é "tornar-se"39. Diferentemente de assumir-se, pois denota uma construção e não uma apropriação (embora ambas não sejam excludentes). O primeiro passo para "tornar-se" homossexual é assumir-se, revelar-se como homossexual. E na contemporaneidade há uma mudança sutil, mas de proporções significativas: cada um é chamado para assumir-se como

38 Expressão usada por Marina Castañeda (2007).

39 ISAY, R. A. Tornar-se gay. São Paulo: Summus, 1998, psiquiatra e psicanalista norte americano, um dos ícones contemporâneos do mundo gay, expressa bem essa tendência na sua obra; "Tornar-se gay". 0 caminho da autoaceitação. Isay conta sua própria odisseia em busca de tornar-se gay, saindo de uma relação heterossexual estável e tendo que assumir os riscos e desafios de uma nova identidade social. 
homossexual a partir de seu próprio habitat, no círculo de suas relações, sejam elas ideológicas, culturais, políticas ou religiosas ${ }^{40}$. Esse processo de "tornar-se homossexual" ganha outra configuração, porque não é um processo de via única, pelo contrário, exige uma contrapartida social. No momento em que alguém num espaço religioso, por exemplo, assume-se como homossexual, há nesse espaço não apenas uma reação a essa assunção, mas também uma pergunta pelo "daqui pra frente". Nesse sentido é inevitável que a Sociedade seja convidada (forçada?) a uma reavaliação de suas posturas diante da questão homossexual nos mais diversos âmbitos ${ }^{41}$.

\section{Os valores homossexuais}

Fugindo do estereótipo ${ }^{42}$ de promíscuas, anarquistas, "despudoradas", pessoas homossexuais têm demonstrado que valores como fidelidade ${ }^{43}$. amizade, companheirismo e respeito são tão fundamentais para elas como se imagina ser para as pessoas heterossexuais em sua maioria. Tem surgido um aumento na literatura divulgada pelos movimentos homossexuais no sentido de esclarecer questões familiares ${ }^{44}$. sucesso no trabalho, terapias com conselhos

40 Essa tendência pode ser observada nas publicações das Edições GLS. Por exemplo, ALMEIDA, P. Desclandestinidade: um homossexual religioso conta a sua história. São Paulo: Summus, 2001. 0 autor compartilha o processo de assunção de sua homossexualidade sem vincular a isso o abandono de sua crença religiosa. É possível perceber que nessa opção há uma cisão entre o espaço institucional e o espaço de fé que não precisam mais ser os mesmos para que se experimente uma relação com o Sagrado.

${ }^{41}$ Essa tendência pode ser observada também em iniciativas governamentais e não governamentais, no âmbito estadual e federal como a publicação de cartilhas contra a homofobia, campanhas contra a discriminação. Por exemplo: GUIA PARA PROFISSIONAIS DA EDUCAÇÃO. Educando para a diversidade: como discutir homossexualidade e direitos humanos nas escolas. Curitiba: CEPAC, 2006. v. 1.

${ }^{42}$ Ver por exemplo a declaração do bispo suíço, naturalizado brasileiro, D. Karl Josef Romer, representante do Conselho Pontifício para a Família em Roma publicada na Revista Veja: "Não sou médico nem psiquiatra. 0 que sei é que pode até haver reciprocidade afetiva forte entre homossexuais, mas a entrega e a complementaridade são extremamente problemáticas para eles mesmos. Pela própria estrutura natural. Não quero nem preciso entrar em pormenores, mas a coisa não é tão simples. Uma relação homossexual é extremamente parcial e fragmentada". (ROMER, K. J. Eles estão errados. Revista Veja, edição 1815, ano 36, n. 32 , p. 11- 15, 13 ago. 2003. páginas amarelas).

${ }^{43}$ A Revista Isto É citou uma pesquisa onde homossexuais dizem que prezam a fidelidade. Isto É, n. 1703, p. 68-72, 22 maio 2002.

${ }^{44}$ Como é o caso, por exemplo, da professora universitária e escritora, Edith Modesto, que, após descobrir 
matrimoniais ${ }^{45}$. tanto para o crescimento e apoio às pessoas homossexuais, como também, para que a sociedade entenda a importância do tema para os homossexuais ${ }^{46}$ e mude sua postura em relação aos mesmos ${ }^{47}$. No entanto, essa tarefa não tem sido muito fácil, entre outros motivos, porque a referência usada em termos de valores não é o próprio valor em si, mas o comportamento das pessoas heterossexuais em relação a esse valor. Nesse caso, a "heterossexualidade" é o padrão, mesmo naqueles que não advogam a homossexualidade contrária à natureza, mas como outra possibilidade de ser, de existir ${ }^{48}$.

A busca por tornar seus valores visíveis no Brasil tem levado grupos e pessoas homossexuais a ultrapassarem diversos limites, inclusive os religiosos, para que esses valores, sentimentos e aspirações sejam percebidos a partir de sua pessoa, de suas vozes e textos. Pessoas e grupos homossexuais têm promovido uma mudança de foco importante quando tentam normalizar a opção sexual, delegando-a, embora visível, à esfera privada e trazendo a público não quem é o homossexual na cama, mas quem de fato o homossexual é na sociedade brasileira contemporânea. Diferentemente de algumas afirmações, revelar-se como homossexual não é apenas jogo de marketing, é fruto da necessidade de mostrar à sociedade que a ideia de

que seu filho era homossexual, fundou o primeiro grupo de pais de homossexuais do Brasil e atualmente, coordena uma ONG de referência para assuntos ligados à relação pais e filhos homossexuais: Associação Brasileira de Pais e Mães de Homossexuais. Para mais detalhes ver: <http://www.gph.org.br/home.asp>.

${ }^{45} \mathrm{Nem}$ todas as pessoas homossexuais defendem o casamento no modelo heterossexual, algumas lutam exclusivamente pelo reconhecimento do direito civil que Ihes garanta, no mínimo, segurança quanto ao que construíram com seus parceiros.

${ }^{46}$ RIESENFELD, R. Papai, mamãe, sou gay! Um guia para compreender a orientação sexual dos filhos. São Paulo: Summus, 2002; HARDIN, K. Autoestima para homossexuais: um guia para o amor próprio. São Paulo: Summus, 2000; BITTENCOURT, S. Uma vida de sucesso! Como uma homossexual brasileira se deu bem na Microsoft. São Paulo: Summus, 2003.

47 Para a Desembargadora do Tribunal de Justiça do Rio Grande do Sul, Maria Berenice Dias: "A valorização da dignidade da pessoa humana como elemento fundamental do estado democrático de direito não pode chancelar qualquer discriminação baseada em características pessoais individuais, repelindo-se qualquer restrição à liberdade sexual do indivíduo, não se podendo admitir desrespeito ou prejuízo em função de sua orientação sexual”. Disponível em: <http://www.gontijo-familia.adv.br/novo/artigos_pdf/Maria_berenice/Uni>. Acesso em: 16 jan. 2008. Ver também: DIAS, 2000.

48 Ver por exemplo, a pesquisa realizada por FÉRES-CARNEIRO, T. et al. A escolha amorosa e interação conjugal na heterossexualidade e na homossexualidade. Psicologia Reflexão Crítica, v. 10, n. 2, p. 351-368, 1997. Em um dos resultados da pesquisa a conclusão é a seguinte: "observa-se que a fidelidade é um atributo significativamente mais valorizado pelos homens heterossexuais do que pelos homossexuais".

Rev. Pistis Prax., Teol. Pastor., Curitiba, v. 4, n. 1, p. 149-176, jan./jun. 2012 
perversão, anormalidade ou doença é puro preconceito. O reconhecimento da condição de homossexual por diversas personalidades ${ }^{49}$ do cenário brasileiro, tais como: políticos de credibilidade, empresários de sucesso, professores, pesquisadores, médicos ou religiosos envolvidos com a defesa dos direitos humanos ou voluntários em projetos sociais têm ajudado a reforçar o fato de que a sexualidade de uma pessoa, sua opção afetiva, não traz os prejuízos tão preconizados por defensores da "imoralidade" homossexual; pelo contrário, têm ajudado a desfazer o abismo entre o preconceito e a realidade concreta. É evidente que aspectos do caráter são distintos da opção sexual de uma pessoa; desvios e acertos tanto podem advir de pessoas homossexuais, quanto de pessoas heterossexuais. Para as pessoas homossexuais e movimentos homossexuais, a vinculação de sua opção sexual e afetiva como desvio de caráter, ou mesmo inaptidão para relacionamentos saudáveis, é completamente injustificável, além de servir para disseminação de ódio e preconceitos, marginalização e exclusão.

\section{Homossexualidades e Cristianismo no Brasil}

As relações entre as pessoas homossexuais e a religião no Brasil, em que pese significativas mudanças nos últimos anos, ainda são marcadas pela ambiguidade e complexidade, principalmente porque tão diversa como a homossexualidade é a expressão da religiosidade no Brasil. Embora, majoritariamente o espaço religioso predominante no Brasil seja de matriz cristã, ele não é monolítico internamente. Suas muitas faces ensejam reações em diferentes direções pelos movimentos e pessoas homossexuais ${ }^{50}$. No que pese essa condição, é possível observar uma tendência predominante nessa relação: a conjugação de homossexualidade

\footnotetext{
49 Embora não seja objetivo do presente capítulo fazer qualquer realce a um argumento baseado em pessoas, como registro de pesquisa, ver, por exemplo, Fernando Gabeira, Deputado Federal pelo PV no Rio de Janeiro e candidato nas eleições de 2008 para prefeito da Cidade do Rio de Janeiro. Informações sobre seus projetos políticos e pela causa homossexual podem ser encontrados em seu site pessoal: Disponível em: <http://www.gabeira.com.br>. Acesso em: 16 jan. 2008.

50 Por exemplo, ao mesmo tempo em que tenham que argumentar contra a patologização da homossexualidade por alguns grupos, têm que encarar a "demonização" por outros.
}

Rev. Pistis Prax., Teol. Pastor., Curitiba, v. 4, n. 1, p. 149-176, jan./jun. 2012 
com religiosidade, seja pela via ética ou moral, seja na busca por uma relação com o Sagrado que ultrapasse a condição sexual. A religião, como se poderia supor, não é abandonada pelas pessoas homossexuais, sob o argumento de que é ultrapassada, engessada, mesquinha, preconceituosa, estigmatizadora e excludente; pelo contrário, é desafiada a se refazer, a se repensar. Nessa relação, no caso do Cristianismo, por exemplo, a Igreja é convidada ao confessionário. Confessionário, pela obviedade evidente, é lugar de confissão, de arrependimento e mudança.

Tradicionalmente, estudos, entrevistas e opiniões de grupos e pessoas ligadas aos movimentos homossexuais têm demonstrado certo consenso a respeito do quão prejudicial a visão cristã tem sido, ao longo da história, à causa homossexual, principalmente por contribuir para uma distorção em sua compreensão identitária. Em sua crítica à postura de alguns grupos do Cristianismo brasileiro em relação à homossexualidade, pessoas e grupos homossexuais têm dito, geralmente, que nenhum argumento cristão contra a homossexualidade sobrevive a uma análise crítica, pois esses argumentos e posturas, na quase totalidade, são frutos de convicções cegas, sendo possível observar que, em grande parte, os mesmos advêm de preferências pessoais. Para Luis Mott (2008), representantes do Cristianismo têm apresentado posturas que violam os direitos humanos, principalmente porque têm lutado para "curar os homossexuais" inspirados em um fundamentalismo bíblico incompatível com a moderna exege$\mathrm{se}^{51}$. Mott (2008) argumenta que Cristianismo e homossexualidade não são incompatíveis porque, segundo ele

o que distingue a mensagem de Cristo, tanto do judaísmo como de outras religiões, é o primado do amor: amai-vos uns aos outros. Homossexualidade é amor, amor ágape, amor eros, amor filos. Onde há amor, Deus aí está, disse João, o discípulo que Jesus amava. Portanto, quando dois homens ou duas mulheres se amam, estão cumprindo a regra áurea do Cristianismo. Todos os textos bíblicos - e são pouquíssimos! que costumam ser usados para justificar a homofobia (ódio à homossexualidade) por parte de cristão fundamentalistas, a moderna exegese comprova que foram ou mal traduzidos, ou mal interpretados. De Sodoma e

51 Ver Entrevista n. 12, sobre MOTT, L. Homossexualidade e cristianismo. Disponível em: <http://www.oocities. org/br/luizmottbr/entrev12.html>. Acesso em: 16 jan. 2008. 
Gomorra, às epístolas paulinas. Se Jesus condenasse os homossexuais, não teria curado o escravo/amante (gay) do centurião. Se o Filho de Deus abominasse o amor unissexual, teria dito ao menos uma palavra contra os "sodomitas" e no entanto, condenou sim os hipócritas e duros de coração, prevendo que os eunucos, prostitutas e publicanos vos precederão no reino dos céus.

O grupo "Amor Igual"52 e a "Comunidade Cristã Gay de São Paulo" lançaram um manifesto ${ }^{53}$ conjunto em 1999, no qual, entre outras questões, apontam uma tendência contemporânea em algumas igrejas e comunidades de fazer com que pessoas homossexuais sejam curadas ou regeneradas, demonstrando traços de intolerância e hipocrisia. O manifesto conclama todas as igrejas cristãs no Brasil a adotar uma nova postura a partir dos seguintes argumentos:

Deus concede a cada pessoa a liberdade de, se quiser, se autoexcluir de Seu Amor pela sua forma de agir voluntária, porém proclama que Ele mesmo não deseja excluir a ninguém, e mais: que efetivamente não exclui a ninguém em razão do seu modo-de-ser [...] Cabe às Igrejas aceitarem dentro de si, do modo que são, todos os homens e mulheres homossexuais que desejem fazer um uso responsável e amoroso da sua sexualidade: aceitar aberta e oficialmente a esses homens e mulheres e a seus companheiros ou companheiras como parte honrada e digna do Corpo de Cristo [...] Cabe às Igrejas orientar os seus fiéis para respeitarem a dignidade de todas as pessoas, na imensa variedade com que Deus as fez, incluindo aí expressamente o direito dos homossexuais de serem como são - com destaque para as crianças e jovens, tanto na posição de quem deve respeitar quanto na de quem deve ser respeitado [...] As Igrejas que não o fizerem estarão se fazendo coniventes com uma indescritível carga de sofrimento e opressão, cúmplices das violências psicológicas e muitas vezes físicas que são cometidas diariamente contra os homossexuais, até o assassinato, e envolvidas na culpa por um imenso número de suicídios de jovens que não conseguiram suportar a carga de desprezo e rejeição dirigida ao seu próprio ser ${ }^{54}$.

\footnotetext{
${ }^{52}$ COMUNIDADE Cristã Gay de São Paulo. Disponível em: <http://tropis.org/amorygual/manifest-pt.html>. Acesso em: 16 jan. 2008.

${ }^{53}$ Esse manifesto pode ser lido na íntegra HOMOSSEXUAIS "curados" nunca foram de fato homossexuais. Disponível em: <http://tropis.org/amorygual/manifest-pt.html>. Acesso em: 16 jan. 2008.

${ }^{54}$ Esse manifesto pode ser lido na íntegra 0 QUE AS IGREJAS são chamadas a fazer. Disponível em: <http://
} 
No entanto, é possível observar que outra tendência em direção oposta à postura de crítica, de combate e enfrentamento tem sido acrescentada, de forma cada vez mais frequente, no sentido de propor uma reinterpretação, reconstrução e revisitação de práticas e ensinos da igreja em respeito à homossexualidade no decorrer da história. Basicamente, insiste-se na transposição de condicionamentos culturais (políticos, ideológicos, etc.) usados para condenar, oprimir e marginalizar as pessoas homossexuais. Nessa postura cada vez mais frequente, pesquisas e argumentos ${ }^{55}$ têm ultrapassado o âmbito das meras opiniões, muitas das quais produzidas no próprio seio homossexual, fixando seus posicionamentos e conclusões em estudos mais aprofundados de autores ligados ao próprio Cristianismo ${ }^{56}$. Nesse sentido há um duplo ganho: a autoridade de estudiosos envolvidos com o Cristianismo e a divisão do ônus e reação da crítica da Igreja para dentro de seus próprios muros ${ }^{57}$.

Essa nova tendência não exclui no cenário brasileiro, os embates entre a militância de movimentos pró-homossexuais e diversas correntes do Cristianismo no Brasil. Com uma lei ${ }^{58}$ sendo discutida no Senado Federal sobre a criminalização da homofobia, têm havido notícias constantes de processos e protestos contra pastores por supostos incitamentos ao preconceito e ódio contra os homossexuais. $\mathrm{O}$ acesso à mídia tem exposto de forma frequente posicionamentos cristãos de uma tendência mais fundamentalista a respeito da homossexualidade, classificando-a, principalmente, como pecado, doença ou sem-vergonhice ${ }^{59}$. Por outro lado, para diversos setores do Cristianismo no Brasil, alguns grupos homossexuais agem irracionalmente, usando armas que sempre criticaram, como por exemplo,

tropis.org/amorygual/manifest-pt.html>. Acesso em: 16 jan. 2008.

55 Entrevistas, debates, artigos.

56 Por exemplo, BOSWELL, J. Cristianismo, tolerância social y homosexualidad. Barcelona: Muchinik, 1993; HELMINIAK, D. A. 0 que a Bíblia realmente diz sobre a homossexualidade. São Paulo: Summus, 1998.

${ }^{57}$ No caso da Igreja Católica tradicionalmente têm sido imposto sobre determinados autores o silencio e a consequente revisão de escritos. No caso das Igrejas Evangélicas, o descredenciamento moral dos autores.

58 ESTADO DE SÃO PAULO. Câmara Dos Deputados. Projeto de Lei 5003/200, 7 de agosto de 2001. Determina sanções às práticas discriminatórias em razão da orientação sexual das pessoas. Disponível em: <http:// www.camara.gov.br/sileg/prop_detalhe.asp?id=31842>. Acesso em: 18 jan. 2008.

${ }^{59}$ Como um dos exemplos, um programa dirigido pelo pastor assembleiano Silas Malafaia. Para ele, Deus fez homem e mulher (heterossexualmente falando) e não nenhum "cromossomo homossexual". 
o policiamento e cerceamento da livre expressão de ser, crer e dizer ${ }^{60}$. De forma paralela a esse cenário de combate, há diversas correntes ligadas à igreja cristã no Brasil (nas suas mais variadas vertentes) e aos grupos homossexuais ${ }^{61}$ procurando diálogos, tentando enxergar pontos comuns, principalmente no sentido de garantir o respeito ao direito de ser diferente. A face mais evidente dessa corrente pode ser vista nos grupos de estudos, nas produções teóricas e nos seminários organizados por Universidades Cristãs respeitadas no Brasil ${ }^{62}$. Outro fator importante nessa relação entre Homossexualidade e Cristianismo é o surgimento de Igrejas Cristãs para o acolhimento de pessoas homossexuais sem o pré-requisito de transformá-las em heterossexuais ou exigir das mesmas o celibato (PEREIRA, 2007):

hoje dedico minha vida na divulgação do evangelho inclusivo de Deus. O Senhor me deu muitas alegrias que superam em muito os tempos de angústia e solidão, tenho um companheiro maravilhoso, vivemos um relacionamento responsável baseado no amor e na fidelidade, nossa relação tem sido uma bênção de Deus. Quem disse que Deus não cura homossexuais? Sou testemunha do poder de cura desta verdade, ao longo do meu ministério tenho visto pessoas que se sentiam indignas, infelizes, machucadas sendo transformadas em pessoas cheias do amor e da graça de Deus (VALÉRIO, 2008).

Por si só, tais tendências apostam numa mudança na teologia dominante a partir da prática. Ou seja, a partir de encontros e desencontros, debates e embates, grupos e pessoas homossexuais têm conseguido trazer para a agenda teológica o tema da homossexualidade quando de

\footnotetext{
60 Alguns sites da internet estão cheios de artigos nesse sentido. E-mails são distribuídos constantemente sobre o tema, citando em grande parte, supostos processos judiciais perpetrados por grupos ou pessoas homossexuais.

${ }^{61}$ Há grupos homossexuais catalogando informações sobre dissertações e teses pró-diálogo produzidas por estudiosos ligados ao Cristianismo no Brasil. Ver, por exemplo, a iniciativa do Grupo Dignidade de Curitiba, ao criar o “CEDOC (Centro de Documentação) Prof. Dr. Luiz Mott”. 0 acervo reúne materiais sobre gays, lésbicas, bissexuais, travestis e transexuais (GLBT), incluindo produções acadêmicas (teses, dissertações, monografias e artigos) livros, documentos, publicações periódicas, informativos, DVDs e fotografias que contam parte da história do Grupo Dignidade e do Movimento GLBT no Brasil. É possível conferir mais informações no site: <http://www.grupodignidade.org.br/ cedoc/>. Acesso em: 18 jan. 2008.

$62 \mathrm{Na}$ vertente cristã ligada ao catolicismo algumas PUCs (PUC-Rio, PUC-São Paulo, por exemplo) e na vertente protestante, Escola Superior de Teologia (EST) e Universidade Metodista de São Paulo (UMESP).
} 
sua relação com o sagrado. Pessoas homossexuais consideram-se filhos e filhas de Deus, abertas ao sagrado, à graça, à comunhão, ao ministério, ao Cristo. Mas como é que as Comunidades Cristãs no Brasil, das mais variadas matizes, as enxergam? De que maneira as definem? A partir de quais pressupostos pensam a identidade homossexual? De qualquer maneira, a questão que se põe à comunidade Cristã não é decidir se as pessoas homossexuais podem sentar à mesa no banquete comunitário, elas já estão presentes. A questão que se põe, portanto, é que tipo de teologia(s) pode surgir desse (nesse) encontro para prolongá-lo.

A investigação apresentada nesse artigo procurou demonstrar que as pessoas homossexuais têm procurado construir sua identidade por outra via que não a da anormalidade, perversão, doença ou pecado. Tal busca incide numa superação de uma mentalidade forjada historicamente sobre preconceitos, exclusão e marginalidade.

Dentre os principais projetos ensejados para desconstruir tal cenário, pessoas homossexuais e teóricos de áreas distintas do saber, propõem uma hermenêutica em cuja base fundamental de leitura surja, a partir da observação das vivências e valores das pessoas homossexuais, pontuando, acima de qualquer outro argumento, o respeito à diversidade, à multiplicidade, à justiça e ao pleno reconhecimento da dignidade da pessoa homossexual, enquanto pessoa humana. Dentre as diversas dimensões de sua vida, pessoas homossexuais têm se aberto ao Sagrado e procurado nas diversas expressões religiosas vigentes no Brasil, um espaço em que essa dimensão espiritual possa se desenvolver plenamente.

\section{Referências}

ALMEIDA, P. Desclandestinidade: um homossexual religioso conta a sua história. São Paulo: Summus, 2001.

BERNARDI, I. Projeto de Lei 5003/2001, 7 de agosto 2001. Determina sanções às práticas discriminatórias em razão da orientação sexual das pessoas. São Paulo: Câmara dos deputados, 2001. Disponível em: <http://www.camara.gov. br/sileg/prop_detalhe.asp?id=31842>. Acesso em: 18 jan. 2008. 
BITTENCOURT, S. Uma vida de sucesso! Como uma homossexual brasileira se deu bem na Microsoft. São Paulo: Summus, 2003.

BOSWELL, J. Cristianismo, tolerância social y homosexualidad. Barcelona: Muchinik, 1993.

CASTAÑEDA, M. A experiência homossexual: explicações e conselhos para os homossexuais, suas famílias e seus terapeutas. São Paulo: A Girafa, 2007.

CENTRO PARANAENSE DE CIDADANIA - CEPAC. Educando para a diversidade: como discutir homossexualidade e direitos humanos nas escolas. Guia para Profissionais da Educação CEPAC, Curitiba, v. 1, n. 1, 2006. Disponível em: <http://mixbrasil.uol.com.br/pride/paradas/educando-para-a-diversidade2. html\#rmcl>. Acesso em: 18 jan. 2008.

COMUNIDADE Cristã Gay de São Paulo. Disponível em: <http://tropis.org/amorygual/>. Acesso em: 16 jan. 2008.

DIAS, M. B. União homossexual: o preconceito e a justiça. Porto Alegre: Livraria do Advogado, 2000.

ESTADO DE SÃO PAULO. Câmara dos Deputados. Projeto de Lei 5003/200, 7 de agosto de 2001. Determina sanções às práticas discriminatórias em razão da orientação sexual das pessoas. Disponível em: <http://www.camara.gov.br/ sileg/prop_detalhe.asp?id=31842>. Acesso em: 18 jan. 2008.

FÉRES-CARNEIRO, T. et al. A escolha amorosa e interação conjugal na heterossexualidade e na homossexualidade. Psicologia Reflexão Crítica, v. 10, n. 2, p. 351-368, 1997.

FRANÇA, I. L.; SIMÕES, J. A. Do "queto" ao mercado. In: GREEN, J. N.; TRINDADE, R. (Org.). Homossexualismo em São Paulo e outros escritos. São Paulo: Ed. da UNESP, 2005. p. 309-336.

FRY, P. Para inglês ver: identidade e política na cultura brasileira. Rio de Janeiro: J. Zahar, 1982.

FRY, P.; MACRAE, E. 0 que é homossexualidade. 2. ed. São Paulo: Brasiliense, 1983. (Coleção Primeiros Passos). 
GREEN, J. N.; TRINDADE, R. (Org.). Homossexualismo em São Paulo e outros escritos. São Paulo: Ed. da UNESP, 2005.

HARDIN, K. Autoestima para homossexuais: um guia para o amor-próprio. São Paulo: Summus, 2000.

HELMINIAK, D. A. O que a Bíblia realmente diz sobre a homossexualidade. São Paulo: Summus, 1998.

HOMOSSEXUAIS dizem que prezam a fidelidade. Isto É, n. 1703, p. 68-72, 22 maio 2002.

HOMOSSEXUAIS “curados" nunca foram de fato homossexuais. Disponível em: <http://tropis.org/amorygual/manifest-pt.html〉. Acesso em: 16 jan. 2008.

ISAY, R. A. Tornar-se gay. São Paulo: Summus, 1998.

MACRAE, E. Em defesa do queto. In: GREEN, J. N.; TRINDADE, R. (Org.). Homossexualismo em São Paulo e outros escritos. São Paulo: Ed. da UNESP, 2005.

MOTT, L. J. Misericórdia: a inquisição portuguesa e a repressão ao nefando pecado de sodomia. In: NOVINSKI, A.; CARNEIRO, M. L. T. (Org.). Inquisição: ensaios sobre mentalidades, heresias e arte. Rio de Janeiro: Expressão e Cultura; São Paulo: EDUSP, 1992. p. 703-838.

MOTT, L. Pagode português: a subcultura gay nos tempos inquisitoriais. Ciência e Cultura, n. 40, p. 120-139, 1988.

MOTT, L. Homossexualidade e Cristianismo. Disponível em: <http://www. oocities.org/br/luizmottbr/entrev12.html>. Acesso em: 16 jan. 2008.

NUNAN, A. Homossexualidade: do preconceito aos padrões de consumo. Rio de Janeiro: Caravansarai, 2003.

O QUE AS IGREJAS são chamadas a fazer. Disponível em: <http://amorygual. sites.uol.com.br/manifesto_port.htm>. Acesso em: 16 jan. 2008.

PEREIRA, R. Casamento evangélico e gay: a nova igreja contemporânea abriga ex-pastores e fiéis expulsos de outras denominações por serem homossexuais. Revista Época, n. 501, 2007. Disponível em: <http://revistaepoca.globo.com/ revista/epoca/0,,edg80693-6014-501,00.html>. Acesso em: 16 jan. 2008. 
PIERONI, G. Os excluídos do reino: a inquisição portuguesa e o degredo para o Brasil colônia. Brasília: Ed. da UnB; São Paulo: Imprensa Oficial do Estado, 2000.

RIESENFELD, R. Papai, mamãe, sou gay! Um guia para compreender a orientação sexual dos filhos. São Paulo: Summus, 2002.

ROMER, K. J. Eles estão errados. Revista Veja, edição 1815, ano 36, n. 32, p. 11-15, 13 ago. 2003. Páginas amarelas.

SILVA, V. G. Representação social dos papéis sexuais ativo e passivo nas relações homoeróticas. Revista Sanitas (UEPB), ano 7, n. 14, 2002.

SOUZA, P. Confidências da carne: o público e o privado na enunciação da sexualidade. Campinas: Ed. da Unicamp, 1997.

VALÉRIO, C. Homossexuais curados e libertos. 2006. Disponível em: <http:// icmsp.blogspot.com/2006/05/homossexuais-curados-e-libertos.html >. Acesso em: 16 jan. 2008.

Recebido: 30/03/2010

Received: 03/30/2010

Aprovado: 25/03/2011

Approved: 03/25/2011 